\title{
Delineation of the Functional Capacity of Human Neonatal Lymphocytes
}

\author{
Judy B. Splawski, ${ }^{\star}$ Diane F. Jelinek, ${ }^{\star}$ and Peter E. Lipsky ${ }^{\ddagger}$ \\ Departments of Pediatrics* and Internal Medicine ${ }^{\ddagger}$ and the Harold C Simmons Arthritis Research Center ${ }^{\ddagger}$ \\ at the University of Texas Southwestern Medical Center, Dallas, Texas 75235
}

\begin{abstract}
Neonatal T cell-B cell collaboration was investigated utilizing a system of $\mathrm{T}$ cell-dependent polyclonal $\mathrm{B}$ cell activation and $\mathrm{Ig}$ secretion. In this system, $T$ cells activated by immobilized antiCD3 provide a potent stimulus for Ig production by adult lymphocytes. By contrast, anti-CD3 stimulation of cord blood lymphocytes generated minimal numbers of Ig-secreting cells. Ig production by neonatal lymphocytes was enhanced by the addition of Staphylococcus aureus or secreted factors from mitogenstimulated adult T cells. Supplementation with IL-2 resulted in the production of large amounts of IgM and small amounts of IgG and IgA, with less Ig produced than by comparable cultures of adult lymphocytes. Neonatal $T$ cells proliferated and produced IL-2 in response to immobilized anti-CD3, and supported $B$ cell proliferation and Ig secretion by adult B cells, although not as effectively as adult $T$ cells. Supernatants from activated neonatal $T$ cells were markedly limited in their capacity to support Ig production by adult B cells. Neonatal B cells could be induced to differentiate in response to anti-CD3-stimulated adult $\mathrm{T}$ cells. However, the amounts of $\mathrm{IgG}$ and $\mathrm{IgA}$ secreted were small compared to adult levels. These studies indicate a relative, but not absolute, functional deficiency of both neonatal B and T cells. (J. Clin. Invest. 1991. 87:545-553.) Key words: $\mathrm{CD3} \bullet$ immunoglobulin • interleukin $2 \cdot$ neonatal B cells $\bullet T$ cells
\end{abstract}

\section{Introduction}

Neonates are deficient in the ability to generate humoral immune responses (1). Part of this deficiency may relate to lack of previous exposure to exogenous antigen. However, the inability to respond to antigens, such as bacterial capsular polysaccharides, even after repeated exposure suggests that the deficient immune responses of neonates may be the result of immaturity of some elements of the immune system at birth (1-3). Delineation of the responsiveness of neonatal cord blood lymphocytes to polyclonal mitogens in vitro has supported the concept that they are functionally deficient compared to adult lymphocytes. For example, pokeweed mitogen (PWM) stimulates the generation of IgM-, IgG-, and IgA-producing cells by adult lymphocytes in vitro, but generates minimal Ig-produc-

Address reprint requests to Dr. Lipsky, Department of Internal Medicine, University of Texas Southwestern Medical Center, 5323 Harry Hines Boulevard, Dallas, TX 75235-8884.

Received for publication 9 August 1990 and in revised form 24 September 1990.

J. Clin. Invest.

(c) The American Society for Clinical Investigation, Inc.

$0021-9738 / 91 / 02 / 0545 / 09 \$ 2.00$

Volume 87, February 1991, 545-553 ing cells (ISC) ${ }^{1}$ from neonatal lymphocytes (4-8). However, recent studies have demonstrated that the $B$ cells induced to secrete Ig in response to PWM are largely surface IgD-negative, postswitch memory B cells (9-11). Therefore, the absence of Ig secretion by the neonatal $B$ cells in response to PWM is consistent with the lack of memory B cells in cord blood, but does not provide information about the functional capabilities of naive neonatal B cells.

Stimulation of cord blood B cells with Staphylococcus aureus (SA), a polyclonal activator that induces Ig production by both memory and naive $B$ cells $(11,12)$, and factors secreted by activated adult $T$ cells (TF) induces the secretion of small amounts of IgM (13). Similarly, Epstein-Barr virus (EBV) transformation also induces neonatal B cells to secrete Ig in vitro, but IgM is the only Ig class produced. These results support the conclusion that some neonatal B cells are functionally competent, but limited to $\operatorname{IgM}$ secretion $(7,8,14)$.

In vitro analysis of the functional capabilities of neonatal $\mathrm{T}$ cells has also suggested that they are functionally immature. Early studies utilizing PWM as the polyclonal stimulator demonstrated suppression of adult Ig secretion by the neonatal $\mathrm{T}$ cells $(5,8,15,16)$. This suppression was mediated by $\mathrm{CD}^{+} \mathrm{T}$ cells rather than $\mathrm{CD}^{+}$suppressor $\mathrm{T}$ cells (17-19). A subpopulation of naive $\mathrm{CD}^{+} \mathrm{T}$ cells has been identified in adult peripheral blood by its expression of a number of different proteins, including CD45RA, the high molecular weight isoform of CD45 (20). As with neonatal T cells, stimulation of the CD45RA ${ }^{+}$population from adult peripheral blood with PWM fails to induce help for $B$ cells but rather elicits suppression (21). The majority of cord blood T cells express CD45RA, suggesting that these neonatal $\mathrm{T}$ cells may be comparable to the $\mathrm{CD}^{+}, \mathrm{CD}^{+} 5 \mathrm{RA}^{+}$suppressor/suppressor-inducer $\mathrm{T}$ cells in adult peripheral blood $(19,22-24)$. Irradiation of the neonatal $\mathrm{T}$ cells has been shown to abolish suppressive activity, but they still remain deficient in the capacity to provide help $(8,24,25)$.

Recently a new method of generating antibody responses in vitro has been described which is unique in that the majority of adult peripheral blood B cells can be induced to secrete Ig, indicating that naive as well as memory $B$ cell populations are induced to differentiate (26). In this system, T cells activated by immobilized monoclonal antibody (MAb) to the CD3 molecular complex support the activation and differentiation of $\mathrm{B}$ cells to ISC in the absence of other polyclonal B cell activators or cell types (27). Helper activity can be elicited from both CD45RA ${ }^{+}$ (naive) and $\mathrm{CD}^{4} 5 \mathrm{RO}^{+}$(memory) $\mathrm{T}$ cell subsets after stimulation with anti-CD3 (28). The magnitude of adult B cell responses induced by the anti-CD3-stimulated $T$ cells is far greater than that resulting from activation with $\mathrm{SA}$ and TF or

1. Abbreviations used in this paper: ISC, immunoglobulin-secreting cells; SA, Staphylococcus aureus, Cowan I strain; TF, supernatants of mitogen-activated T cells. 
PWM. T cell contact, but not HLA identity is required for these responses (27). This model system, therefore, appeared to be an appropriate one to analyze the capacity of neonatal lymphocytes to participate in T cell-B cell collaboration leading to the secretion of antibody. Utilizing this system, the functional capabilities of neonatal T and B cells were delineated.

\section{Methods}

Cell preparation. Peripheral blood mononuclear cells (PBMC) were isolated from heparinized venous blood of healthy adult volunteers by centrifugation over sodium diatrizoate/ficoll gradients (Pharmacia, Inc., Piscataway, NJ) as described (29). Neonatal lymphocytes were collected from the cord blood of healthy newborns at the time of delivery and mononuclear cells were obtained as above.

Culture medium. All cultures were carried out in medium RPMI 1640 Gibco Laboratories, Grand Island, NY), supplemented with penicillin G $(200 \mathrm{U} / \mathrm{ml})$, gentamicin $(10 \mu \mathrm{g} / \mathrm{ml}$, Sigma Chemical Co., St. Louis, MO), L-glutamine $(0.3 \mathrm{mg} / \mathrm{ml})$, and $10 \%$ fetal bovine serum (FBS) (Microbiological Associates, Walkersville, MD).

Reagents. SA (Pansorbin) was purchased from Calbiochem-Behring Corp., La Jolla, CA, and used at a final concentration of 1:60,000 (vol/vol). PWM (Gibco Laboratories) was used at a final concentration of $10 \mu \mathrm{g} / \mathrm{ml}$. PHA was purchased from Wellcome Reagents, Division of Burroughs Wellcome Co., Research Triangle Park, NC. 4 $\beta$-Phorbol 12-myristate 13-acetate (PMA) was purchased from Sigma Chemical Co. and was dissolved in ethanol for use in culture. Purified recombinant interleukin 2 (IL-2) was provided by the Cetus Corporation, Emeryville, CA.

$M A b$. The MAb, 64.1, is an IgG2a MAb directed at the CD3 molecular complex on mature $T$ cells $(30,31) .64 .1$ was purified from ascites fluid by passage over a column of Sepharose $4 \mathrm{~B}$ coupled with staphylococcal protein A. OKT8 (American Type Culture Collection [ATCC], Rockville, MD) is an IgG2a MAb directed at the CD8 molecule. L234 (ATCC) is an IgG2a MAb directed at monomorphic HLA-DR determinants. Anti-Tac, a MAb directed at the p55 component of the IL-2 receptor (CD25), was generously provided by Dr. T. Waldmann, National Cancer Institute, National Institutes of Health, Bethesda, MD (32)

Cell separation. PBMC from adult peripheral blood and cord blood were depleted of monocytes and natural killer (NK) cells by incubation with $5 \mathrm{mM} \mathrm{L}$-leucine methyl ester (Sigma Chemical Co.) in serum-free medium $(33,34)$. After washing, B cells were depleted of $T$ cells by two cycles of rosetting with neuraminidase-treated sheep red blood cells (SRBC) (35). Adult B cells prepared in this fashion are $>90 \%$ CD20 positive, as has been previously established (36). Cord blood B cells were $70-75 \% \mathrm{CD} 20$ positive and $75-90 \% \mathrm{CD} 19$ positive. Approximately $85-90 \%$ of both the cord and adult CD20-positive B cells stained positively for IgD. The B cell preparations contained $<1 \%$ CD3-positive cells. Sedimented rosette-forming cells from the first centrifugation were treated with isotonic $\mathrm{NH}_{4} \mathrm{Cl}$ to lyse the $\mathrm{SRBC}$ and then passed over a nylon wool column. The resulting cell population contained $<1 \%$ esterase-staining cells and $>95 \% \mathrm{CD3}^{+} \mathrm{T}$ cells (36). Cord blood $\mathrm{T}$ cell populations were also $>95 \% \mathrm{CD3}^{+}$and were $>95 \%$ $\mathrm{CD}^{2} 5 \mathrm{RA}^{+}$. CD4 enriched populations were obtained after panning to remove $\mathrm{CD}^{+}$and $\mathrm{HLA}-\mathrm{DR}^{+}$cells as previously described (37). Monocyte depletion was demonstrated by the absence of proliferation in response to PHA by the cord and adult $\mathrm{T}$ cell populations. T cells were subjected to treatment with mitomycin C $(40 \mu \mathrm{g} / \mathrm{ml}$, Sigma Chemical Co.) or 2,000 rad of $\gamma$ irradiation before culture.

Generation of mitogen-stimulated $T$ cell supernatants $(T F)$. T cells were suspended in medium with $10 \% \mathrm{FBS}$ at a concentration of $5 \times 10^{6}$ cells $/ \mathrm{ml}$ and incubated with $1 \mu \mathrm{g} / \mathrm{ml}$ of PHA and $1 \mathrm{ng} / \mathrm{ml}$ of PMA for 2 $\mathrm{h}$ at $37^{\circ} \mathrm{C}$. The cells were then washed and resuspended in fresh culture medium at $5 \times 10^{6} / \mathrm{ml}, 2 \mathrm{ml}$ per $17 \times 100$-mm round-bottom tube. After $48 \mathrm{~h}$, the supernatants were harvested, filtered, and stored at $-20^{\circ} \mathrm{C}$ until used (36). TF was added to the well so that the final concentration was $25 \% \mathrm{vol} / \mathrm{vol}$. In some cases, T cell supernatants were generated by incubating $\mathrm{T}$ cells $\left(5 \times 10^{6}\right.$ cells per well, $1 \mathrm{ml}$ per well $)$ in 64.1-coated wells and harvesting the supernatants after $48 \mathrm{~h}$.

Culture conditions. RPMI 1640 or $0.05 \mathrm{M}$ Tris at $\mathrm{pH} 9.5$ was used to dilute the 64.1 , the concentration was adjusted to $4 \mu \mathrm{g} / \mathrm{ml}$ and $50 \mu \mathrm{l}$ were placed in each well of 96-well microtiter plates (Costar Data Packaging, Cambridge, MA). After incubation at room temperature for 1-5 $\mathrm{h}$, the wells were washed twice with medium to remove nonadherent MAb before the addition of cells (38). Routine cultures were carried out in triplicate in a total volume of $200 \mu \mathrm{l}$ per well. T cells or $\mathrm{CD}^{+}$cells were added at the density of $1.0 \times 10^{5}$ per well and $\mathrm{B}$ cells were added at $2.5 \times 10^{4}$ per well. The cultures were incubated at $37^{\circ} \mathrm{C}$ in a humidified atmosphere of $5 \% \mathrm{CO}_{2}$ and $95 \%$ air. At the end of a 5-d incubation period, the cells were harvested for determination of ISC. Supernatants for quantitation of Ig secretion were harvested at varying time points as indicated.

Proliferation assays. Culture conditions used for the assay of lymphocyte $\left[{ }^{3} \mathrm{H}\right]$ thymidine incorporation were identical to those used for the generation of ISC. The cells were incubated for 3-5 d with $1 \mu \mathrm{Ci}$ of $\left[{ }^{3} \mathrm{H}\right]$ thymidine $(6.7 \mathrm{Ci} / \mathrm{mM}$; New England Nuclear, Boston, MA) present for the last $18 \mathrm{~h}$. The cells were harvested onto glass filter paper and $\left[{ }^{3} \mathrm{H}\right]$ thymidine incorporation determined by liquid scintillation spectroscopy.

Detection of ISC. ISC were detected by a reverse hemolytic plaque assay that has been described in detail (39). For this assay, staphylococcal protein A-coupled SRBC are the indicator cells and the developing antiserum is a rabbit anti-human $\operatorname{Ig}$ (IgM, IgG, and IgA) (Cappel Laboratories, West Chester, PA) diluted 1:50, and the complement source is a 1:20 dilution of guinea pig serum (Pel-Freeze Biologicals, Inc., Rogers, AR) that had previously been absorbed with SRBC. All data are expressed as the mean number of ISC per 1,000 B cells initially cultured.

Measurement of Ig secretion. Ig in the culture supernatants was quantitated utilizing isotype specific ELISA assays as previously described $(11,40)$. The sensitivities of the specific assays are IgM $24 \mathrm{ng} /$ $\mathrm{ml}$, and $\mathrm{IgG}$ and $\mathrm{IgA} 12 \mathrm{ng} / \mathrm{ml}$.

IL-2 assay. Supernatants to be assayed for IL-2 production were obtained after incubation of neonatal and adult $\mathrm{T}$ cells $\left(1.0 \times 10^{5} /\right.$ well $)$ for $72 \mathrm{~h}$ with immobilized anti-CD3 in the presence of $5 \mu \mathrm{g} / \mathrm{ml}$ antiCD25 MAb. Supernatants were filtered and frozen before assay. IL-2 production was determined by incubation of CTLL cells $\left(5 \times 10^{3}\right.$ cells per well) suspended in $100 \mu$ l of medium containing $10 \%$ FBS with 100 $\mu l$ of the culture supernatant to be assayed or various concentrations of recombinant IL-2 diluted in culture medium. $\left[{ }^{3} \mathrm{H}\right] \mathrm{Thymidine}$ incorporation was assessed after $28 \mathrm{~h}$ with $\left[{ }^{3} \mathrm{H}\right]$ thymidine present for the last 8 h. IL-2 production was determined by comparing CTLL $\left[{ }^{3} \mathrm{H}\right]$ thymidine incorporation supported by supernatants with that supported by known concentrations of recombinant IL-2 (41).

Statistical analysis. Statistical analysis of the data was carried out utilizing the paired $t$ test.

\section{Results}

Anti-CD3 stimulation of neonatal lymphocytes is not sufficient to induce Ig secretion. The initial experiments examined the capacity of anti-CD3 stimulation to induce ISC generation by neonatal $B$ and $T$ cells. Although anti-CD3 induced the generation of a large number of ISC by adult lymphocytes, minimal numbers of ISC were induced from cord lymphocytes (Table I). The addition of SA to provide an additional activation signal for the B cells resulted in a consistent increase in the number of ISC generated by the anti-CD3-stimulated neonatal lymphocytes, whereas co-stimulation of anti-CD3-activated neonatal lymphocyte cultures with both SA and TF markedly increased the generation of ISC. In the absence of anti-CD3 stimulation, $\mathrm{SA}$ and TF induced only modest generation of ISC from neona- 
Table I. Ig Production by Neonatal Lymphocytes Stimulated with Combinations of Polyclonal Activators

\begin{tabular}{|c|c|c|c|c|c|c|c|c|c|}
\hline \multirow{2}{*}{$\begin{array}{l}\text { Lymphocyte } \\
\text { source }\end{array}$} & \multirow{2}{*}{$\begin{array}{l}\text { Addition to } \\
\text { culture }\end{array}$} & \multicolumn{4}{|c|}{ Without anti-CD3 } & \multicolumn{4}{|c|}{ With anti-CD3 } \\
\hline & & ISC & IgM & IgG & IgA & ISC & IgM & IgG & IgA \\
\hline & & & & $n g / m l$ & & & & $n g / m l$ & \\
\hline \multirow[t]{4}{*}{ Adult } & Nil & 0.0 & ND & ND & 55 & 720.0 & 3,920 & 2,240 & 1,920 \\
\hline & TF & 134.0 & 1,560 & 380 & 296 & 708.6 & 4,480 & 2,000 & 1,872 \\
\hline & SA & 8.0 & 37 & 240 & 156 & 849.8 & 4,160 & 2,480 & 1,952 \\
\hline & $\mathrm{SA}+\mathrm{TF}$ & 307.0 & 2,720 & 4,480 & 928 & 766.2 & 3,840 & 1,000 & 1,712 \\
\hline \multirow[t]{4}{*}{ Cord 1} & Nil & 0.0 & ND & ND & ND & 0.0 & ND & ND & ND \\
\hline & TF & 0.0 & ND & ND & ND & 0.0 & 100 & ND & ND \\
\hline & SA & 0.0 & ND & ND & ND & 2.6 & 1,600 & ND & ND \\
\hline & $\mathrm{SA}+\mathrm{TF}$ & 3.2 & 800 & ND & ND & 163.0 & 1,480 & ND & ND \\
\hline \multirow[t]{4}{*}{ Cord 2} & Nil & 0.0 & ND & ND & ND & 0.4 & ND & ND & ND \\
\hline & TF & 0.0 & ND & ND & ND & 6.4 & 270 & 17 & ND \\
\hline & SA & 0.0 & ND & ND & ND & 54.2 & 1,360 & ND & ND \\
\hline & $\mathrm{SA}+\mathrm{TF}$ & 19.2 & 510 & ND & ND & 232.0 & 1,520 & ND & ND \\
\hline \multirow[t]{4}{*}{ Cord 3} & Nil & 0.2 & ND & ND & ND & 0.0 & ND & ND & ND \\
\hline & TF & 0.0 & ND & ND & ND & 1.4 & 190 & 20 & ND \\
\hline & SA & 0.0 & ND & ND & ND & 26.6 & 264 & ND & ND \\
\hline & $\mathrm{SA}+\mathrm{TF}$ & 0.4 & 400 & ND & ND & 113.8 & 1,720 & ND & ND \\
\hline
\end{tabular}

Cord or adult B cells were incubated with mitomycin C-treated cord or adult CD4 ${ }^{+}$cells. Supernatants were collected for determination of Ig content and cells were harvested for determination of ISC (per $10^{3} \mathrm{~B}$ cells) on day 6. ND, not detectable.

tal lymphocytes. These results contrast with the responses noted in cultures of anti-CD3-stimulated adult lymphocytes, in which the addition of SA or TF alone or in combination had little effect on the generation of ISC.

Adult lymphocytes secreted IgG and IgA in addition to IgM after stimulation with TF or SA and TF and in response to stimulation with anti-CD3 (Table I). The addition of SA and TF to the anti-CD3-stimulated adult lymphocytes did not result in a dramatic increase in the secreted $\mathrm{Ig}$, nor an alteration of the isotype of Ig secreted. In the absence of anti-CD3 stimulation, neonatal lymphocytes secreted Ig only after stimulation with SA and TF and the response was limited to IgM. AntiCD3 stimulation of the neonatal B and T cells did not result in Ig secretion but IgM secretion was induced by the addition of either adult TF or SA to these cultures. The amount of IgM produced in response to $S A$ and $T F$ was markedly augmented by co-stimulation with anti-CD3. The responses of the neonatal lymphocytes varied in that some of the preparations required SA alone and others required SA and adult TF for the maximal response to anti-CD3 stimulation. Even with maximal stimulation, however, only IgM was secreted by day 6 .

The addition of large concentrations of IL-2 (50 U/ml) could also augment IgM production by anti-CD3-activated neonatal lymphocytes and in addition, induced the secretion of a modest amount of IgG and IgA (Table II). Addition of smaller amounts of IL-2 $(10 \mathrm{U} / \mathrm{ml})$ had a much more modest effect, supporting a small amount of IgM and IgG secretion in one of five experiments. The amount of Ig secreted in cultures supported by $50 \mathrm{U} / \mathrm{ml}$ of IL-2 was significantly less than that produced by anti-CD3-stimulated adult $B$ and $T$ cells with or without supplemental IL-2.

Examination of the kinetics of Ig production in IL-2-supported cultures of neonatal $\mathrm{T}$ and $\mathrm{B}$ cells demonstrated ongo- ing production of Ig for up to $20 \mathrm{~d}$ (Fig. 1). Secretion of IgM could be observed as early as the 5 th $d$ of culture. Detection of IgG and IgA secretion was delayed compared to IgM. Although the amount of IgA increased throughout the culture period, it represented only a minor portion of the Ig produced in contrast to cultures of anti-CD3-stimulated adult $B$ and $T$ cells.

Functional capacity of neonatal $T$ cells. The next experiments examined the functional capacity of neonatal $T$ cells. Anti-CD3 induced DNA synthesis by neonatal T cells that was not significantly different from that exhibited by adult $\mathrm{T}$ cells (Fig. 2). Secretion of IL-2 by cord T cells in response to stimulation with anti-CD3 was also observed, although the amount of

Table II. Supplemental IL-2 Induces IgM, IgG, and IgA Secretion by Anti-CD3-stimulated Neonatal B and T Cells

\begin{tabular}{llccc}
\hline & & \multicolumn{3}{c}{ Ig isotype secreted } \\
\cline { 3 - 5 } Cells & Addition & IgM & IgG & IgA \\
\hline \multirow{4}{*}{ Cord } & & \multicolumn{4}{c}{$n g / m l$} \\
& Nil & $11 \pm 11$ & $3 \pm 3$ & $6 \pm 6$ \\
& IL-2 (10) & $83 \pm 44$ & $14 \pm 10$ & $6 \pm 6$ \\
& IL-2 (50) & $2,075 \pm 615$ & $395 \pm 143$ & $53 \pm 1$ \\
Adult & Nil & $10,174 \pm 1,692$ & $2,520 \pm 583$ & $8,083 \pm 886$ \\
& IL-2 (50) & $11,572 \pm 4,424$ & $3,404 \pm 1,109$ & $6,383 \pm 1,811$
\end{tabular}

Cord and adult $B$ cells and irradiated $T$ cells were incubated with immobilized anti-CD3 and with or without IL-2 $(10$ or $50 \mathrm{U} / \mathrm{ml})$. Supernatants were harvested after a 10-d incubation for quantitation of the Ig secreted by ELISA. The results are the mean \pm SEM for five experiments. 




Figure 1. Kinetics of Ig production by anti-CD3-stimulated neonatal $B$ and T cells supplemented with IL-2. Cord B cells $\left(1.0-2.5 \times 10^{4}\right.$ per well) were incubated with irradiated cord T cells $\left(1.0 \times 10^{5}\right.$ per well) in the presence of immobilized anti-CD3 and $50 \mathrm{U} / \mathrm{ml}$ of IL-2. Supernatants were harvested from triplicate wells on the indicated days for. quantitation of Ig isotypes secreted by ELISA. The results are expressed as the mean \pm SEM for four different experiments.

IL-2 produced by the neonatal T cells was somewhat less than that produced by adult $T$ cells (adult $T$ cells $42 \mathrm{U} / \mathrm{ml}$; cord $\mathrm{T}$ cells $27.6 \pm 3.3 \mathrm{U} / \mathrm{ml}$ ) (Fig. 3).

The helper function of anti-CD3-stimulated neonatal $T$ cells was investigated initially by examining their ability to support B cell proliferation. As can be seen in Fig. 4, anti-CD3-stimulated neonatal $T$ cells induced proliferation of neonatal B cells, although less effectively than adult $\mathrm{T}$ cells. As can be seen in Table III, neonatal T cells also promoted adult B cell proliferation, but not as effectively as adult $\mathrm{T}$ cells. The addition of adult TF did not overcome this difference. These results indicate that anti-CD3-stimulated neonatal $T$ cells can promote DNA synthesis by both adult and neonatal B cells, but are less effective in this regard than adult $T$ cells even when cultures are supplemented with cytokine-rich $T$ cell supernatants.

The capacity of neonatal $\mathrm{T}$ cells to promote ISC generation by adult $\mathrm{B}$ cells was also examined (Table IV). Anti-CD3-activated neonatal $\mathrm{CD}^{+}$cells supported the generation of ISC by adult $B$ cells in the absence of additional co-stimulation, although not as effectively as adult $\mathrm{CD}^{+}$cells. The addition of

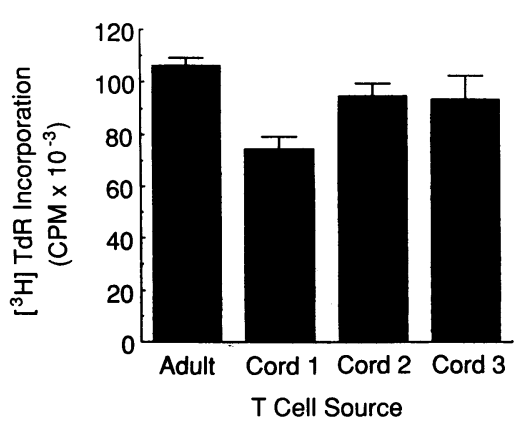

Figure 2. DNA synthetic responses of anti-CD3-stimulated adult and neonatal CD4+ T cells. $T$ cells $(1$ $\times 10^{5}$ per well) were incubated with immobilized anti-CD3. $\left[{ }^{3} \mathrm{H}\right]$ Thymidine was added $18 \mathrm{~h}$ before harvest of the cells on day 5 . The results are expressed as the mean \pm SEM of triplicate samples.

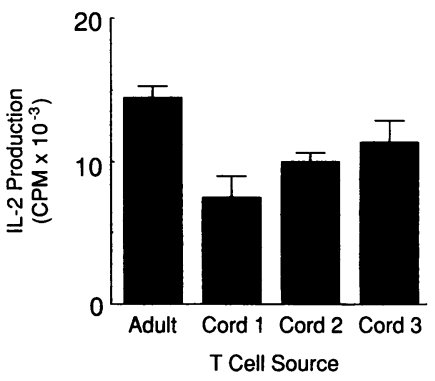

Figure 3. IL-2 production by anti-CD3-stimulated neonatal and adult $\mathrm{T}$ cells. Neonatal or adult $T$ cells $\left(1 \times 10^{5}\right.$ per well $)$ were incubated with immobilized anti-CD3 in the presence of $5 \mu \mathrm{g} / \mathrm{ml}$ of antibody to the $\mathrm{p} 55$ component of the IL-2 receptor. Supernatants were collected at $72 \mathrm{~h}$ and analyzed for the production of IL- 2 by

$\left[{ }^{3} \mathrm{H}\right]$ thymidine incorporation of CTLL cells. The results are expressed as the mean \pm SEM of the triplicate samples.

adult TF augmented the response of adult $B$ cells stimulated by anti-CD3-activated neonatal $\mathrm{CD} 4^{+}$cells, although the number of ISC generated remained less than that supported by the antiCD3-stimulated adult $\mathrm{CD}^{+}$cells. Anti-CD3-stimulated neonatal $\mathrm{CD}^{+}$cells promoted the secretion of $\operatorname{IgG}$ and $\mathrm{IgA}$ in addition to IgM by the adult B cells (Table V). Secretion of all Ig isotypes was augmented by the addition of adult TF. In some, but not all experiments, neonatal $\mathrm{CD}^{+}$cells were able to support Ig secretion by adult $B$ cells to the same extent as the adult $\mathrm{CD}^{+}$cells when adult TF was added. These results indicate that neonatal $\mathrm{CD}^{+} \mathrm{T}$ cells could provide help to adult $\mathrm{B}$ cells, but that optimal support of Ig secretion required the addition of lymphokine-rich supernatants from activated adult $T$ cells. Thus, neonatal T cells appear to be quantitatively, but not qualitatively deficient in the capacity to provide help for B cells.

The above studies suggested that anti-CD3-stimulated neonatal $T$ cells might be deficient in the capacity to secrete sufficient cytokines to support $B$ cell differentiation. Therefore, the ability of supernatants generated by activated neonatal $\mathrm{T}$ cells to support adult B cell Ig secretion was examined (Table VI). TF from adult $T$ cells supported the secretion of $\operatorname{IgA}, \mathrm{IgG}$, and IgM from SA-stimulated adult B cells. By contrast, TF from neonatal $T$ cells was markedly deficient in the capacity to support the secretion of Ig by SA-stimulated adult B cells. The addition of IL-2 to the SA-stimulated B cells supported a modest amount of Ig secretion and augmented $B$ cell differentiation supported by neonatal $\mathrm{T}$ cell supernatants, but not to the level

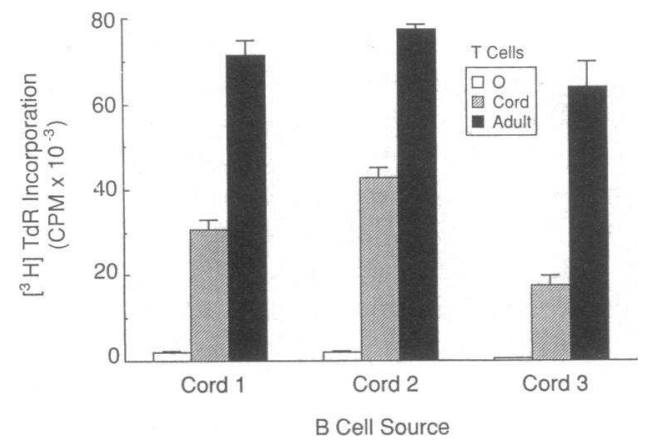

Figure 4. Neonatal B cell DNA synthesis induced by anti-CD3stimulated neonatal T cells. Cord B cells $\left(2.5 \times 10^{4}\right.$ per well $)$ were incubated with or without irradiated cord or adult $T$ cells $\left(1 \times 10^{5}\right.$ per well) stimulated with immobilized anti-CD3. $\left[{ }^{3} \mathrm{H}\right]$ Thymidine was present for the last $18 \mathrm{~h}$ of a 3-d culture. The results are expressed as the mean $\pm \mathrm{SEM}$ of the triplicate samples. 
Table III. Support of Adult B Cell Proliferation by Neonatal T Cells

\begin{tabular}{|c|c|c|c|c|}
\hline \multirow[b]{3}{*}{ T cell source } & \multicolumn{4}{|c|}{ Addition to culture } \\
\hline & \multicolumn{2}{|c|}{ Without anti-CD3 } & \multicolumn{2}{|c|}{ With anti-CD3 } \\
\hline & $-\mathrm{TF}$ & $+\mathrm{TF}$ & $-\mathrm{TF}$ & $+\mathrm{TF}$ \\
\hline & \multicolumn{4}{|c|}{$\mathrm{cpm} \times 10^{-3}$} \\
\hline No $T$ cells & $0.1 \pm 0.0$ & $1.5 \pm 0.2$ & $1.0 \pm 0.1$ & $1.7 \pm 0.1$ \\
\hline Adult $T$ & $0.3 \pm 0.0$ & $15.7 \pm 0.9$ & $68.4 \pm 6.9$ & $78.6 \pm 7.5$ \\
\hline Adult $\mathrm{CD}^{+}$ & $0.3 \pm 0.1$ & $16.5 \pm 0.6$ & $60.1 \pm 7.9$ & $84.0 \pm 8.8$ \\
\hline Cord $1 \mathrm{CD}^{+}$ & $0.5 \pm 0.1$ & $4.6 \pm 0.5$ & $17.9 \pm 1.3$ & $41.3 \pm 1.7$ \\
\hline Cord $2 \mathrm{~T}$ & $1.8 \pm 0.3$ & $4.5 \pm 0.7$ & $17.7 \pm 0.2$ & $31.3 \pm 4.0$ \\
\hline Cord $2 \mathrm{CD}^{+}$ & $0.8 \pm 0.2$ & $3.7 \pm 0.3$ & $22.1 \pm 1.0$ & $35.9 \pm 5.3$ \\
\hline Cord $3 \mathrm{~T}$ & $1.6 \pm 0.2$ & $6.1 \pm 0.3$ & $22.8 \pm 1.3$ & $37.8 \pm 1.3$ \\
\hline Cord $3 \mathrm{CD}^{+}$ & $0.2 \pm 0.0$ & $4.7 \pm 0.5$ & $23.5 \pm 2.2$ & $54.6 \pm 6.6$ \\
\hline
\end{tabular}

Adult B cells were incubated with mitomycin C-treated adult or cord $\mathrm{T}$ cells or $\mathrm{CD}^{+}$cells in the presence or absence of anti-CD3 and harvested after a 5-d incubation. $\left[{ }^{3} \mathrm{H}\right]$ Thymidine incorporation by TF or anti-CD3-activated cord or adult T cells was $<1.3 \pm 0.4 \times 10^{3}$ cpm.

supported by adult TF. By contrast, supplementation with IL-2 did not augment Ig production supported by adult TF. These results suggest that there are differences in the amounts or types of cytokines secreted by neonatal and adult $T$ cells.

Functional capacity of neonatal B cells. The ability of neonatal $B$ cells to respond to anti-CD3-activated adult $T$ cells was also examined. Adult $\mathrm{CD}^{+}$cells support ISC generation by the neonatal $\mathrm{B}$ cells in the absence of additional co-stimulation (Fig. 5). This contrasts with the absence of ISC generation by the neonatal $\mathrm{B}$ cells in response to anti-CD3-stimulated neonatal $\mathrm{CD}^{+}$cells. However, the magnitude of the response was much less than that induced from adult $B$ cells. The addition of either SA, adult TF, or SA and TF variably enhanced the response, but not to the levels observed with adult $B$ cells. In the absence of anti-CD3 stimulation, SA and TF induced minimal numbers of ISC ( $<20$ ISC per 1,000 B cells).

Examination of the Ig isotypes secreted by neonatal B cells in response to the anti-CD3-stimulated adult $\mathrm{CD} 4^{+}$cells at day 6 demonstrated a small amount of IgG secretion in addition to
Table IV. Neonatal CD4 $4^{+} T$ Cell Support of the Generation of ISC from Adult $B$ Cells

\begin{tabular}{|c|c|c|c|c|}
\hline \multirow[b]{2}{*}{ T cell source } & \multicolumn{2}{|c|}{ Control } & \multicolumn{2}{|c|}{ Anti-CD3 stimulated } \\
\hline & $-\mathrm{TF}$ & $+\mathrm{TF}$ & $-\mathrm{TF}$ & $+\mathrm{TF}$ \\
\hline & \multicolumn{4}{|c|}{ ISC per $10^{3}$ B cells } \\
\hline Adult & $0.0 \pm 0.0$ & $84.2 \pm 24.1^{*}$ & $837.6 \pm 107.7$ & $669.2 \pm 80.6$ \\
\hline Cord & $0.1 \pm 0.0$ & $7.8 \pm 3.0^{\ddagger}$ & $111.9 \pm 41.3$ & $276.4 \pm 36.3^{* \neq}$ \\
\hline
\end{tabular}

Adult B cells were incubated with mitomycin C-treated adult or cord $\mathrm{CD}^{+} \mathrm{T}$ cells in the presence or absence of immobilized anti-CD3 or adult TF. ISC generation was determined on day 5 . The results are expressed as the mean \pm SEM for three adult $B$ and $T$ cell populations and seven cord $\mathrm{T}$ cell populations.

* Significant enhancement of ISC generation with addition of adult TF $(P<0.05)$.

${ }^{\ddagger}$ Cord T cells supported significantly less ISC from adult B than adult T cells $(P<0.05)$.

IgM (Table VII). IgA secretion was observed in some experiments after a 10-d incubation (data not shown). Addition of TF or IL-2 (not shown) variably enhanced Ig secretion in the cultures supported by adult $\mathrm{T}$ cells in contrast to responses observed with neonatal $\mathrm{T}$ cells.

\section{Discussion}

The current studies were carried out to delineate the full functional potential of human neonatal B and T lymphocytes. To achieve this, a model system was employed that permits functional activation of both naive and memory $T$ and $B$ cells and, therefore, could be used to examine specific aspects of neonatal $T$ and B cell collaboration (26). The results demonstrate that with optimal activation and cytokine support, neonatal B cells can be induced to differentiate and secrete all three major Ig isotypes by neonatal $\mathrm{T}$ cells. These findings may have clinical implications with regard to amplifying antibody responses of neonates in vivo.

Previous in vitro studies of neonatal lymphocyte responses have demonstrated deficiencies in the ability to generate antibody (1). A number of features of neonatal lymphocytes may contribute to altered responsiveness. Thus, cord blood contains predominantly naive $\mathrm{B}$ cells and $\mathrm{T}$ cells that respond poorly to

Table V. Neonatal T Cell Support of Immunoglobulin Secretion by Adult B Cells

\begin{tabular}{|c|c|c|c|c|c|c|}
\hline \multirow{2}{*}{$\begin{array}{l}\text { T cell } \\
\text { source }\end{array}$} & \multicolumn{3}{|c|}{$-\mathrm{TF}$} & \multicolumn{3}{|c|}{$+\mathrm{TF}$} \\
\hline & IgM & $\lg G$ & IgA & IgM & IgG & $\lg A$ \\
\hline & \multicolumn{6}{|c|}{$n g / m l$} \\
\hline Adult & $8,834 \pm 2,241$ & $3,458 \pm 1,300$ & $1,950 \pm 422$ & $7,632 \pm 2,104$ & $3,632 \pm 1,319$ & $1,701 \pm 404$ \\
\hline Cord & $1,552 \pm 478$ & $436 \pm 165$ & $478 \pm 152$ & $4,924 \pm 1,462$ & $1,560 \pm 606$ & $1,176 \pm 388$ \\
\hline
\end{tabular}

Adult B cells were cultured with adult or cord $\mathrm{CD} 4^{+} \mathrm{T}$ cells and immobilized anti-CD3 in the presence or absence of adult TF. Supernatants were harvested for the determination of Ig secretion after a 5- or 6-d incubation. The results are expressed as the mean \pm SEM for five experiments with adult $\mathrm{B}$ and $\mathrm{T}$ cell populations and nine cord $\mathrm{T}$ cell populations. Cord $\mathrm{T}$ supported less Ig secretion than adult $\mathrm{T}$ cells $(P<0.05)$. TF enhanced the Ig production supported by cord $\mathrm{T}$ but not adult $\mathrm{T}$ cells $(P<0.05)$. 
Table VI. Support of Adult B Cell Ig Secretion by Cord and Adult T Cell Supernatants

\begin{tabular}{|c|c|c|c|c|c|}
\hline \multirow[b]{2}{*}{ Expt. } & \multirow[b]{2}{*}{ Mitogen } & \multirow[b]{2}{*}{ TF } & \multicolumn{3}{|c|}{$\begin{array}{c}\text { Ig secreted by SA-stimulated } \\
\text { adult B cells }\end{array}$} \\
\hline & & & IgM & IgG & IgA \\
\hline & & & & $n g / m l$ & \\
\hline \multirow[t]{8}{*}{1} & Anti-CD3 & Adult 1 & 1,720 & $>2,000$ & 560 \\
\hline & & Adult 2 & 1,400 & $>2,000$ & 312 \\
\hline & & Cord 1 & 500 & $<15$ & $<15$ \\
\hline & & Cord 2 & 220 & $<15$ & $<15$ \\
\hline & PHA/PMA & Adult 1 & 1,520 & $>2,000$ & 432 \\
\hline & & Adult 2 & 1,460 & 640 & 196 \\
\hline & & Cord 1 & 800 & $<15$ & $<15$ \\
\hline & & Cord 2 & 560 & $<15$ & $<15$ \\
\hline \multirow[t]{7}{*}{2} & PHA/PMA & IL-2 only & $<24$ & 123 & 39 \\
\hline & & Adult & 810 & 2,863 & 402 \\
\hline & & Adult + IL-2 & 909 & 2,241 & 402 \\
\hline & & Cord 1 & 96 & 621 & 150 \\
\hline & & Cord $1+$ IL-2 & 507 & 1,836 & 192 \\
\hline & & Cord 2 & $<24$ & 180 & 66 \\
\hline & & Cord $2+$ IL-2 & 198 & 1,071 & 150 \\
\hline
\end{tabular}

Adult B cells were incubated with SA and TF generated from adult or cord $T$ cells in response to immobilized anti-CD3 or PHA/PMA.

Supernatants were harvested for determination of Ig secretion on day 5 . IL-2 was added to the indicated wells at a concentration of $50 \mathrm{U} / \mathrm{ml}$.

many mitogens. PWM drives primarily memory B cells and generates minimal Ig producing cells from neonatal $B$ and $T$ cells (4-9). EBV and the combination of SA and adult TF stimulate some Ig secretion, but the response is small and limited to $\operatorname{IgM}(7,8,14)$. These latter results have suggested that the capacity of neonatal B cells to produce Ig is deficient. Irradiated neonatal T cells can provide help for PWM-stimulated adult B cells, suggesting that neonatal $T$ cells can serve as helper cells (8). However, they appear to be considerably less potent in this regard than adult $T$ cells. It is difficult, however, to draw con-

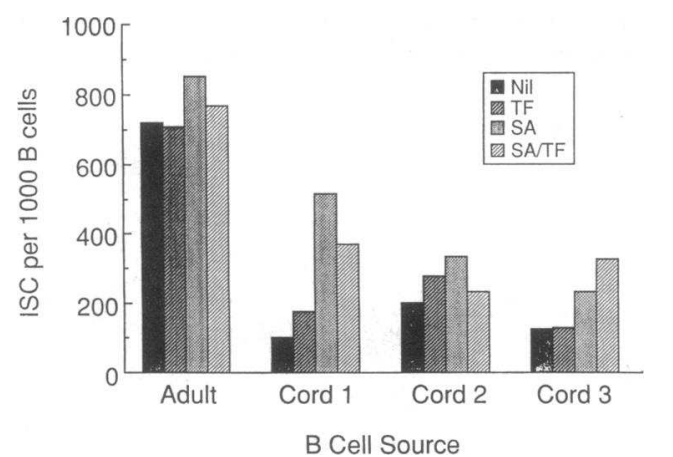

Figure 5. Anti-CD3-activated adult T cell support of neonatal ISC generation. Adult or cord B cells $\left(2.5 \times 10^{4}\right.$ per well $)$ were cultured with mitomycin $C$-treated adult $\mathrm{CD}^{+} \mathrm{T}$ cells $\left(1.0 \times 10^{5}\right.$ per well $)$ in the presence of anti-CD3, with or without SA or mitogenstimulated adult $\mathrm{T}$ cell supernatants. ISC generation was assayed on day 5 . clusions concerning the ability of neonatal $\mathrm{T}$ cells to function as helper T cells for neonatal B cells, inasmuch as it is clear from the current studies that neonatal B cells require a much greater array of activation signals than adult B cells. Thus, the deficient responses of the neonatal lymphocytes could represent true functional immaturity, but the degree of nonresponsiveness may not have been accurately assessed previously because of the use of stimuli that do not activate naive B cells effectively in vitro.

Cord blood B cells differ from adult B cell populations in a number of ways, including the small percentage of memory cells and the large percentages of naive and $\mathrm{CD5}^{+} \mathrm{B}$ cells $(42$, 43). However, in contrast to PWM, stimulation of adult lymphocytes with immobilized anti-CD3 induces Ig secretion from most adult $B$ cells, indicating that differentiation of naive and memory B cell populations can be induced (26). Specifically, both $\mathrm{IgD}^{+}$naive $\mathrm{B}$ cells and $\mathrm{CD5}^{+} \mathrm{B}$ cells isolated from adult peripheral blood secrete Ig in response to anti-CD3 activated adult T cells (L. Vernino and P. E. Lipsky, unpublished observation). Therefore, the use of this model system was thought to be an appropriate way to evaluate the functional capabilities of neonatal B cells and their capacity to collaborate with activated $T$ cells for the induction of antibody secretion.

Anti-CD3 stimulation of adult $T$ cells is sufficient to induce the secretion of large amounts of Ig by adult B cells. However, anti-CD3 stimulation of neonatal B and T cells did not induce ISC generation or Ig secretion. This did not appear to relate to a diminished responsiveness of the neonatal $\mathrm{T}$ cells to signaling by immobilized anti-CD3 at the concentrations tested. Cord $\mathrm{T}$ cells express CD3 at a density that is comparable to memory $T$ cells. Although cord $T$ cells and naive $\left(C_{4} 4 \mathrm{RA}^{+}\right)$adult $\mathrm{T}$ cells have been reported to be deficient in their ability to be activated and to produce IL- 2 in response to soluble antibody to $\mathrm{CD} 3$ and $\mathrm{CD} 2$, the results reported here indicate that neonatal $\mathrm{T}$ cells can be induced to proliferate and secrete IL-2 by immobilized anti-CD3 (44-47). These results are consistent with the demonstration that naive adult $\mathrm{T}$ cells expressing CD45RA are responsive to signaling by immobi-

Table VII. Adult T Cell Support of Neonatal $B$ Cell Differentiation

\begin{tabular}{lcccc}
\hline & & \multicolumn{3}{c}{ Immunoglubulin isotype } \\
\cline { 3 - 5 } B cells & TF & IgM & IgG & IgA \\
\hline \multirow{3}{*}{ Adult } & & & $n g / m l$ & \\
& - & 3,920 & 2,240 & 1,920 \\
Cord 1 & + & 4,480 & 2,000 & 1,872 \\
& - & 4,800 & 88 & $<12$ \\
Cord 2 & + & 4,320 & 164 & $<12$ \\
& - & 2,160 & 58 & $<12$ \\
Cord 3 & + & 2,688 & 116 & $<12$ \\
& - & 3,440 & 118 & $<12$ \\
& + & 4,080 & 182 & $<12$
\end{tabular}

Cord or adult B cells were incubated with mitomycin C-treated adult $T$ cells stimulated with immobilized anti-CD3 in the presence or absence of adult TF. Supernatants were collected after a 6-d incubation and analyzed for Ig content. 
lized anti-CD3, and after activation are capable of producing IL-2 and supporting adult $B$ cells proliferation and differentiation (28). Therefore, neonatal $\mathrm{T}$ cells can be activated through the CD3 molecular complex, although they appear to require the enhanced signaling capacity of immobilized 64.1 for the induction of proliferation and IL-2 production.

Although there was clear evidence that immobilized antiCD3 induced neonatal T cell activation, proliferation, and IL-2 production, neonatal $\mathrm{T}$ cells were deficient in the capacity to function as efficient helper cells for B cell responses. Thus, anti-CD3 activated neonatal $T$ cells induced proliferation of adult and neonatal $\mathrm{B}$ cells, but the responses induced by the neonatal $T$ cells were less than those elicited by adult $T$ cells. Both neonatal and adult CD45RA ${ }^{+} \mathrm{T}$ cells suppress adult lymphocyte responses to a variety of stimuli $(6,21,24,28)$. It seemed unlikely that suppressive influences could account for the limited capacity of neonatal $\mathrm{T}$ cells to provide help for B cells. In this regard, irradiation has been shown to prevent suppression of adult lymphocyte responses by PWM-stimulated neonatal $T$ cells $(8,24)$. Moreover, suppression caused by antiCD3-stimulated adult $T$ cells is completely prevented by irradiation or mitomycin $C$ treatment (48). In addition, the $T$ cell populations were treated with leucine methyl ester to remove NK cells and were depleted of $\mathrm{CD}^{+} \mathrm{T}$ cells to minimize suppression. Even after these maneuvers to limit suppression, neonatal $T$ cells supported suboptimal B cell activation. Despite their limitations, it is clear, however, that anti-CD3-stimulated neonatal $\mathrm{CD}^{+}$cells are capable of inducing contact-dependent $B$ cell activation in the absence of other cell types, but do so less well than adult $\mathrm{CD} 4^{+} \mathrm{T}$ cells.

The limited capacity of neonatal T cells to provide help for B cells was more apparent when production of $\mathrm{Ig}$ by B cells was examined and especially when the ability to provide help for neonatal B cell differentiation was assessed. This appears to reflect the increased helper cell signals required to promote Ig production by cord B cells. The diminished capacity of neonatal $T$ cells to support Ig production by adult $B$ cells appeared to be quantitative rather than qualitative as IgG and IgA were secreted in addition to IgM, albeit each in lesser amounts than secreted in cultures supported by adult $T$ cells. Addition of adult TF to cultures of anti-CD3-activated cord $T$ cells and adult $B$ cells augmented ISC generation and the secretion of all Ig isotypes, suggesting that cytokine production by the neonatal $\mathrm{T}$ cells was limiting. Comparison of the ability of TF obtained from neonatal and adult $T$ cells to support adult $B$ cell Ig secretion confirmed the conclusion that deficient cytokine production by the neonatal $\mathrm{T}$ cells contributed to the submaximal support of $B$ cell differentiation.

Previous reports indicate that CD45RA ${ }^{+}$adult $\mathrm{T}$ cells and cord T cells secrete IL- 2 in response to a variety of stimuli (49-51). In the current studies, stimulation of neonatal T cells with immobilized anti-CD3 resulted in the production of IL-2, although the amount produced was slightly less than that produced by the adult $T$ cells. Even though the cord T cell supernatants contained IL-2, they were markedly limited in the capacity to support Ig secretion by SA-stimulated adult B cells. Analysis of the cord $T$ cell supernatants indicated that they were not suppressive and that the addition of IL- 2 enhanced the responses of SA-stimulated adult B cells, but not to the levels noted with adult TF. These results indicate that the lesser amount of IL-2 in the neonatal T cell supernatants might contribute to their decreased capacity to support B cell responses, but could not entirely explain the deficiency. Cord blood and both adult human and murine naive $T$ cells have been reported to be deficient in the ability to produce other cytokines, including IFN- $\gamma$, IL-3, and IL-4, that may play a role in supporting B cell responses $(49,50,52-54)$. Although none of these cytokines alone promote Ig secretion by SA-stimulated B cells, each can enhance the secretion supported by IL- $2(40,55,56)$. Therefore, deficient production of one or more of these cytokines may contribute to the deficient support of B cell differentiation by the neonatal $\mathrm{T}$ cells.

Neonatal B cells can be induced to secrete Ig in response to SA and adult TF or EBV. However, neonatal B cell responses are deficient in both the quantity of Ig secreted and in the capacity to produce IgG and IgA. Previous results have suggested that neonatal B cells are limited in their capacity to differentiate into ISC and to switch to Ig isotypes other than IgM, although their capacity to differentiate in a system involving $\mathrm{T}$ cell-B cell collaboration has not been completely evaluated because PWM, the most frequently employed T cell-dependent $B$ cell activator, is not an optimal stimulus for naive lymphocytes. Examination of the potential of neonatal B cells to collaborate with $T$ cells indicated that they could be activated by anti-CD3-activated adult $T$ cells. DNA synthesis of neonatal $B$ cells induced by anti-CD3-activated adult $T$ cells was comparable to that of adult B cells. Despite this clear-cut evidence of the capacity of neonatal B cells to receive activation signals from adult $\mathrm{T}$ cells, the generation of ISC and Ig secretion were much less than that observed for adult B cells. Although, preliminary analysis by limiting dilution suggests that 1 in 125 neonatal B cells can be induced to secrete immunoglobulin when supported by adult $T$ cells in this system, this is still considerably less than the precursor frequencies obtained with adult B cells (26).

It should be noted that neonatal B cells responded more poorly to anti-CD3-activated $\mathrm{T}$ cells than either adult $\mathrm{IgD}^{+}$ naive $\mathrm{B}$ cells or adult $\mathrm{CD}^{+} \mathrm{B}$ cells, indicating that they exhibited diminished functional responsiveness beyond that predicted from their phenotype. Since anti-CD3-stimulated adult $T$ cells supply all of the activation signals and cytokines necessary for the support of maximal adult B cell differentiation, addition of SA or adult TF does not usually augment the response. However, the addition of either SA or adult TF to cultures of neonatal B cells and anti-CD3-activated adult $T$ cells enhanced the production of $\mathrm{Ig}$, suggesting that differentiation of neonatal B cells requires additional signals and cytokines beyond that necessary for adult $B$ cell differentiation. The exact nature of these signals and their role in T cell-B cell collaboration remains to be determined.

Previous results have suggested that neonatal B cells are limited in their capacity to secrete IgG and IgA. The current studies clearly indicate that neonatal B cells can be induced to produce IgG and IgA after stimulation with anti-CD3-activated adult $T$ cells or anti-CD3-activated neonatal $T$ cells and exogenous cytokines. The induction of IgG and IgA secretion from neonatal B cells that were uniformly IgM positive at the initiation of culture suggests that anti-CD3-stimulated $T$ cells induced isotype switching. Induction of Ig isotype switch is also suggested by the delay in IgG and IgA production compared to IgM secretion. A significant increase in IgG and IgA, but not IgM, production between days 10 and 20 was appreciated in five experiments. Anti-CD3-activated $T$ cells appear to be an important factor in inducing this putative isotype switch be- 
cause neonatal B cells did not secrete IgG or IgA when stimulated with SA and TF in the presence of neonatal or adult $T$ cells even when cultured for up to $20 \mathrm{~d}$ (data not shown). Thus, anti-CD3-activated $\mathrm{T}$ cells appear to provide a unique signal necessary for Ig isotype switching by a small population of neonatal B cells. The secretion of IgG and IgA was only observed when anti-CD3-activated neonatal lymphocyte cultures were supplemented with exogenous cytokines, and especially large concentrations of IL-2. Thus, one difference between adult and neonatal B cells may be the concentration of IL-2, and perhaps other cytokines, necessary to induce differentiation.

In summary, stimulation of neonatal lymphocytes with immobilized anti-CD3 has demonstrated unique functional patterns of both neonatal $T$ cells and $B$ cells that distinguish them from adult lymphocytes. The capacity of neonatal B cells to secrete IgM and also IgG and IgA after appropriate stimulation is greater than previously demonstrated and suggests that deficient antibody production of neonates may be overcome by provision of more optimal activation and differentiation stimuli.

\section{Acknowledgments}

We would like to thank Ms. Bonnie Ferguson-Darnell for her excellent technical assistance; Dr. Lynette Casey, Melanie King, and Valencia Hoffman for procurement of the cord blood samples; and Ms. Alice Wiggins for preparation of the manuscript.

This work was supported by National Institutes of Health grants DK01620, AR-09989, and AR-36169.

\section{References}

1. Gathings, W. E., H. Kubagawa, and M. D. Cooper. 1981. A distinctive pattern of B cell immaturity in perinatal humans. Immunol. Rev. 57:107-126.

2. Granoff, D. M., P. G. Shackelford, B. K. Suarez, M. H. Nahm, K. L. Cates T. V. Murphy, R. Karasic, M. T. Osterholm, J. P. Pandey, and R. S. Daum. 1986 Hemophilus influenzae type b disease in children vaccinated with type b polysaccharide vaccine. N. Engl. J. Med. 315:1584-1590.

3. Kayhty, H., V. Karanko, H. Peltola, and P. H. Makela. 1984. Serum antibodies after vaccination with Haemophilus influenza type b capsular polysaccharide and responses to reimmunization: no evidence of immunologic tolerance or memory. Pediatrics. 74:857-865.

4. Wu, L. Y. F., A. Blanco, M. D. Cooper, and A. R. Lawton. 1976. Ontogeny of B-lymphocyte differentiation induced by pokeweed mitogen. Clin. Immunol Immunopathol. 5:208-217.

5. Haywood, A. R., and A. R. Lawton. 1977. Induction of plasma cell differentiation of human fetal lymphocytes: evidence for functional immaturity of $\mathrm{T}$ and B cells. J. Immunol. 119:1213-1217.

6. Miyawaki, T., N. Moriya, T. Nagaoki, and N. Taniguchi. 1981. Maturation of B-cell differentiation ability and T-cell regulatory function in infancy and childhood. Immunol. Rev. 57:61-87.

7. Andersson, U., A. G. Bird, S. Britton, and R. Palacios. 1981. Humoral and cellular immunity in humans studied at the cell level from birth to two years. Immunol. Rev. 57:5-38.

8. Tosato, G., I. T. Magrath, I. R. Koski, N. J. Dooley, and R. M. Blaese. 1980. B cell differentiation and immunoregulatory $\mathrm{T}$ cell function in human cord blood lymphocytes. J. Clin. Invest. 66:383-388.

9. Kuritani, T., and M. D. Cooper. 1982. Human B cell differentiation. II. Pokeweed mitogen-responsive B cells belong to a surface immunoglobulin Dnegative subpopulation. J. Exp. Med. 155:1561-1566.

10. Saiki, O., and P. Ralph. 1982. IgM- and IgD- bearing peripheral blood lymphocytes differentiate to IgM but not IgG or IgA immunoglobulin-secreting cells. Eur. J. Immunol. 12:506-510.

11. Jelinek, D. F., J. B. Splawski, and P. E. Lipsky. 1986. Human peripheral blood B lymphocyte subpopulations: functional and phenotypic analysis of surface IgD positive and negative subsets. J. Immunol. 136:83-92.

12. Saiki, O., and P. Ralph. 1981. Induction of human immunoglobulin secretion: synergistic effect of B cell mitogen Cowan I plus T cell mitogens or factors. $J$. Immunol. 127:1044-1047.

13. Ruuskanen, O., W. B. Pittard III, K. Miller, G. Pierce, R. U. Sorensen, and
S. H. Polmar. 1980. Staphylococcus aureus Cowan I-induced immunoglobulin production in human cord blood lymphocytes. J. Immunol. 125:411-413.

14. Steel, C. M., J. Philipson, E. Arthur, S. E. Gardiner, M. S. Newton, and R. V. McIntosh. 1977. Possibility of EB virus preferentially transforming a subpopulation of human B lymphocytes. Nature (Lond.). 270:729-730.

15. Olding, L. B., R. A. Murgita, and H. Wigzell. 1977. Mitogen-stimulated lymphoid cells from human newborns suppress the proliferation of maternal lymphocytes across a cell-impermeable membrane. J. Immunol. 119:1109-1114.

16. Oldstone, M. B. A., A. Tishon, and L. Moretta. 1977. Active thymus derived suppressor lymphocytes in human cord blood. Nature (Lond.). 269:333335 .

17. Papadogiannakis, N., S. A. Johnsen, and L. B. Olding. 1985. Human fetal/neonatal suppressor activity: relation between OKT phenotypes and sensitivity to prostaglandin E2 in maternal and neonatal lymphocytes. Am. J. Reprod. Immunol. Microbiol. 9:105-110.

18. Cheng, H., A. H. Sehon, and G. Delespesse. 1985. Human cord blood suppressor T lymphocytes. I. Phenotype and target of the inducer of suppressor cell factor. Am. J. Reprod. Immunol. Microbiol. 9:93-99.

19. Kingsley, G., C. Pitzalis, A. P. Waugh, and G. S. Panayi. 1988. Correlation of immunoregulatory function with cell phenotype in cord blood lymphocytes. Clin. Exp. Immunol. 73:40-45.

20. Tedder, T. F., L. T. Clement, and M. D. Cooper. 1985. Human lymphocyte differentiation antigens HB-10 and HB-11. I. Ontogeny of antigen expression. J. Immunol. 134:2983-2988.

21. Morimoto, C., N. L. Letvin, J. A. Distaso, W. R. Aldrich, and S. F. Schlossman. 1985. The isolation and characterization of the human suppressor inducer T cell subset. J. Immunol. 134:1508-1515.

22. Gerli, R., A. Bertotto, F. Spinozzi, C. Cernetti, F. Grignaniand, and P. Rambotti. 1986. Phenotypic dissection of cord blood immunoregulatory T-cell subsets by using a two-color immunofluorescence study. Clin. Immunol. Immunopathol. 40:429-435.

23. Notarangelo, L. D., P. Panina, L. Imberti, P. Malfa, A. G. Ugazio, and A. Albertini. 1988. Neonatal T4 ${ }^{+}$lymphocytes: analysis of the expression of $4 B 4$ and 2H4 antigens. Clin. Immunol. Immunopathol. 46:61-67.

24. Clement, L. T., P. E. Vink, and G. E. Bradley. 1990. Novel immunoregulatory functions of phenotypically distinct subpopulations of $\mathrm{CD}^{+}$cells in the human neonate. J. Immunol. 145:102-108.

25. Hayward, A. R., and P. M. Lydyard. 1979. B cell function in the newborn Pediatrics. 64:758-764.

26. Amoroso, K., and P. E. Lipsky. 1990. Frequency of human B cells differentiating in response to anti-CD3 activated T cells. J. Immunol. 145:3155-3161

27. Hirohata, S. D. F. Jelinek, and P. E. Lipsky. 1988. T cell-dependent activation of $B$ cell proliferation and differentiation by immobilized monoclonal antibodies to CD3. J. Immunol. 240:3736-3744.

28. Hirohata, S, and P. E. Lipsky. 1989. T cell regulation of human B cell proliferation and differentiation: regulatory influences of CD45R ${ }^{+}$and CD45R T4 cell subsets. J. Immunol. 142:2597-2607.

29. Boyum, A. 1968. Isolation of mononuclear cells and granulocytes from human blood: isolation of mononuclear cells by one centrifugation and of granulocytes by combining centrifugation and sedimentation at 1 g. Scan. J. Clin. Lab Invest. 21 (Suppl. 97):77-89.

30. Hansen, J., P. Martin, P. Beatty, E. Clark, and J. Ledbetter. 1984. Human $T$ lymphocyte cell surface molecules defined by the workshop monoclonal antibodies ("T cell protocol"). In Leucocyte Typing. A. Bernard, L. Boumsell, J. Dausset, C. Milstein, and S. F. Schlossman, editors. Springer-Verlag, Berlin. 195 212.

31. Kung, P. C., G. Goldstein, E. L. Reinherz, and S. F. Schlossman. 1979. Monoclonal antibodies defining distinctive human $\mathrm{T}$ cell surface antigens Science (Wash. DC). 206:347-349.

32. Uchiyama, T., S. Broder, and T. A. Waldmann. 1981. A monoclonal antibody (anti-Tac) reactive with activated and functionally mature human $T$ cells. I. Production of anti-Tac monoclonal antibody and distribution of Tac $(+)$ cells. J. Immunol. 126:1393-1397.

33. Thiele, D. L., M. Kurosaka, and P. E. Lipsky. 1983. Phenotype of the accessory cell necessary for mitogen-stimulated $T$ and $B$ cell responses in human peripheral blood: delineation by its sensitivity to the lysosomotrophic agent, Lleucine methyl ester. J. Immunol. 131:2282-2290.

34. Thiele, D. L., and P. E. Lipsky. 1985. Modulation of human natural killer cell function by L-leucine methyl ester: monocyte-dependent depletion from human peripheral blood mononuclear cells. J. Immunol. 134:786-793.

35. Galili, U., and M. Schlesinger. 1974. The formation of stable E rosettes after neuraminidase treatment of either human peripheral blood lymphocytes or of sheep red blood cells. J. Immunol. 112:1628-1634.

36. Jelinek, D. F., and P. E. Lipsky. 1985. The roles of T cell factors in activation, cell cycle progression, and differentiation of human B cells. J. Immunol 134:1690-1701.

37. Wysocki, L. J., and V. L. Sato. 1978. "Panning” for lymphocytes: a method for cell selection. Proc. Natl. Acad. Sci. USA. 75:2844-2848.

38. Geppert, T. D., and P. E. Lipsky. 1987. Accessory cell independent prolif- 
eration of human T4 cells stimulated by immobilized monoclonal antibodies to CD3. J. Immunol. 138:1660-1666.

39. Rosenberg, S. A., and P. E. Lipsky. 1979. Monocyte dependence of pokeweed mitogen-induced differentiation of immunoglobulin-secreting cells from human peripheral blood mononuclear cells. J. Immunol. 122:926-931.

40. Splawski, J. B., D. F. Jelinek, and P. E. Lipsky. 1989. Immunomodulatory role of interleukin 4 on the secretion of immunoglobulin by human B cells. $J$. Immunol. 142:1569-1575.

41. Baroja, M. L., and J. L. Ceuppens. 1987. More exact quantification of interleukin-2 production by addition of anti-Tac monoclonal antibody to cultures of stimulated lymphocytes. J. Immunol. Methods. 98:267-270.

42. Hardy, R. R., K. Hayakawa, M. Shimizu, K. Yamasaki, and T. Kishimoto. 1987. Rheumatoid factor secretion from human Leu-1 ${ }^{+}$B cells. Science (Wash. DC). 236:81-83.

43. Gadol, N., and K. A. Ault. 1986. Phenotypic and functional characterization of human leu/l (CD5) B cells. Immunol. Rev. 93:23-34.

44. Byrne, J. A., J. L. Butler, and M. D. Cooper. 1988. Differential activation requirements for virgin and memory T cells. J. Immunol. 141:3249-3257.

45. Papadogiannakis, N., S. A. Johnsen, and L. B. Olding. 1986. Monocyte-regulated hyporesponsiveness of human cord blood lymphocytes to OKT3-monoclonal antibody-induced mitogenesis. Scand. J. Immunol. 23:91-99.

46. Gerli, R., A. Bertotto, S. Crupi, C. Arcangeli, I. Marinelli, F. Spinozzi, C. Cernetti, P. Angelella, and P. Rambotti. 1989. Activation of Cord T lymphocytes. I. Evidence for a defective T cell mitogenesis induced through the CD2 molecule. J. Immunol. 142:2583-2589.

47. Bertotto, A., R. Gerli, L. Lanfrancone, S. Crupi, C. Arcangeli, C. Cernetti, F. Spinozzi, and P. Rambotti. 1990. Activation of cord T lymphocytes. II. Cellular and molecular analysis of the defective response induced by anti-CD3 monoclonal antibody. Cell. Immunol. 127:247-259.
48. Hirohata, S., L. S. Davis, and P. E. Lipsky. 1989. Role of IL-2 in the generation of $\mathrm{CD}^{+}$suppressors of human B cell responsiveness. J. Immunol. 142:3104-3112.

49. Sanders, M. E., M. W. Makgoba, S. O. Sharrow, D. Stephany, T. A Springer, H. A. Young, and S. Shaw. 1988. Human memory T lymphocytes express increased levels of three cell adhesion molecules (LFA-3, CD2, and LFA 1) and three other molecules (UCHL1, CDw29, and Pgp-1) and have enhanced IFN- $\gamma$ production. J. Immunol. 140:1401-1407.

50. Kibler, R., M. J. Hicks, A. L. Wright, and L. M. Taussig. 1986. A comparative analysis of cord blood and adult lymphocytes: interleukin- 2 and interferon production, natural killer cell activity, and lymphocyte populations. Diagn. Im munol. 4:201-208.

51. Fairfax, C. A., and M. S. Borzy. 1988. Interleukin 2 production, proliferative response, and receptor expression by cord blood mononuclear cells. J. Clin. Lab. Immunol. 27:63-67.

52. Budd, R. C., and J. C. Cerottini, and H. R. MacDonald. 1987. Selectively increased production of Interferon- $\gamma$ by subsets of Lyt-2+ and L3T4+ T cells identified by expression of Pgp-1. J. Immunol. 138:3583-3586.

53. Salmon, M., G. D. Kitas, and P. A. Bacon. 1989. Production of lymphokine mRNA by CD45R ${ }^{+}$and CD45R ${ }^{-}$helper $T$ cells from human peripheral blood and by human CD4 ${ }^{+} \mathrm{T}$ cell clones. J. Immunol. 143:907-912.

54. Powers, G. D. A. K. Abbas, and R. A. Miller. 1988. Frequencies of IL-2 and IL-4-secreting $T$ cells in naive and antigen stimulated lymphocyte populations. J. Immunol. 140:3352-3357.

55. Jelinek, D. F., J. B. Splawski, and P. E. Lipsky. 1986. The roles of interleukin 2 and interferon-gamma in human B cell activation, growth and differentiation. Eur. J. Immunol. 16:925-932.

56. Tadmori, W., D. Feingersh, S. C. Clark, and Y. S. Choi. 1989. Human recombinant IL-3 stimulates B cell differentiation. J. Immunol. 142:1950-1955. 